\title{
Prevalence and spatial distribution of Theileria parva in cattle under crop-livestock farming systems in Tororo District, Eastern Uganda
}

\author{
Dennis Muhanguzi ${ }^{1,2 *}$, Kim Picozzi ${ }^{2}$, Jan Hatendorf ${ }^{3}$, Michael Thrusfield ${ }^{4}$, Susan Christina Welburn², \\ John David Kabasa ${ }^{1}$ and Charles Waiswa ${ }^{1}$
}

\begin{abstract}
Background: Tick-borne diseases (TBDs) present a major economic burden to communities across East Africa. Farmers in East Africa must use acaracides to target ticks and prevent transmission of tick-borne diseases such as anaplasmosis, babesiosis, cowdriosis and theileriosis; the major causes of cattle mortality and morbidity. The costs of controlling East Coast Fever (ECF), caused by Theileria parva, in Uganda are significant and measures taken to control ticks, to be cost-effective, should take into account the burden of disease. The aim of the present work was to estimate the burden presented by T. parva and its spatial distribution in a crop-livestock production system in Eastern Uganda.

Methods: A cross sectional study was carried out to determine the prevalence and spatial distribution of T. parva in Tororo District, Uganda. Blood samples were taken from all cattle (n: 2,658) in 22 randomly selected villages across Tororo District from September to December 2011. Samples were analysed by PCR and T. parva prevalence and spatial distribution determined.

Results: The overall prevalence of T. parva was found to be 5.3\%. Herd level prevalence ranged from 0\% to 21\% with majority of the infections located in the North, North-Eastern and South-Eastern parts of Tororo District. No statistically significant differences in risk of infection were found between age classes, sex and cattle breed.

Conclusions: T. parva infection is widely distributed in Tororo District, Uganda. The prevalence and distribution of $T$. parva is most likely determined by spatial distribution of $R$. appendiculatus, restricted grazing of calves and preferential tick control targeting draft animals.
\end{abstract}

Keywords: East Coast fever, Prevalence, p104-based PCR, Theileria parva, Tororo District

\section{Background}

Tick-borne diseases (TBDs) - anaplasmosis, babesiosis, cowdriosis and theileriosis - cause significant economic losses to the livestock sector in tropical and subtropical regions of the world [1-3]. In Tanzania the annual losses to the livestock sector from TBD have been calculated as US\$ 364 million, including mortality of 1.3 million cattle. Theileriosis was estimated to account for $70 \%$ of these losses while

\footnotetext{
*Correspondence: luckydenno@gmail.com

${ }^{1}$ College of Veterinary Medicine Animal Resources and Biosecurity, Makerere University, P.O. Box 7062, Kampala, Uganda

${ }^{2}$ Centre for Infectious Diseases, School of Biomedical Sciences, College of Medicine and Veterinary Medicine, The University of Edinburgh, Chancellor's Building, 49 Little France Crescent, Edinburgh, EH16 4SB, UK

Full list of author information is available at the end of the article
}

anaplasmosis, babesiosis and cowdriosis accounted for the remaining 30\% [4]. Theileriosis caused by Theileria parva, a protozoan parasite transmitted by the brown ear tick (Rhipicephalus appendiculatus), infects and transforms lymphocytes, causing a severe and often fatal lymphocytosis called East Coast Fever (ECF) [5]. East Coast fever results in immuno-depression, secondary bacterial infection of the upper respiratory tract, fever and anorexia often leading to death if not treated within three weeks [5-7].

Across Eastern Uganda, cattle are kept under a traditional management system of communal grazing or tethering $[8,9]$. Cattle are therefore continuously exposed to ticks and thus T. parva and other tick-borne infections with some of them progressing to clinical disease 
(for example ECF). This presents both benefits and risks with regard to TBD epidemiology and in particular to ECF. In the case of anaplasmosis and babesiosis, solid maternal immunity has previously been demonstrated and infection and recovery of calves reduces chances for infection and progression to clinical disease as adults $[10,11]$. As such, adult cattle that are infected as calves, recover from such infections with the help of maternal immunity and are very resistant to re-infection as adults. This epidemiological situation is called endemic (enzootic) stability and is known to be absolute for both anaplasmosis and babesiosis [10,12]. In case of $T$. parva, which is known to be more virulent than both Anaplasma and Babesia species, all cattle above 6 months of age are at equal risk of infection with $T$. parva and progression to clinical disease (ECF) $[12,13]$. East coast fever is more severe than both babesiosis and anaplasmosis with mortality rates varying from $10 \%-20 \%$ in susceptible calves to over $90 \%$ in susceptible adults [12-14]. Consequently, very high morbidity and mortality rates due to ECF are expected in areas such as Eastern Uganda, where relatively low transmission rates of $T$. parva have previously been recorded in lowland grazing areas, a topographic situation that typifies Tororo District $[15,16]$. Conversely, low morbidities and mortalities are expected in highland areas where high transmission and seroconversion at a very young age is expected $[15,16]$. Even in areas of very high T. parva transmission, considerable calf morbidities and mortalities have been recorded [13]. These epidemiological observations indicate that ECF remains an important impediment to livestock production in both areas of low and high transmission rates $[13,16]$.

Farmers in East Africa may use acaracides to target ticks and prevent tick-borne diseases but in Tororo District over $70 \%$ of the farmers do not use any acaracides for tick control but rather occasionally hand pick ticks to reduce their populations on cattle [17]. Control options need to be designed that maintain the delicate balance of endemic stability. To examine the extent to which $T$. parva (ECF) presents a problem to the smallscale cattle production systems in Eastern Uganda, a cross sectional study was carried out to determine both the prevalence and spatial distribution of T. parva across Tororo District. This information is key for guiding and prioritising TBD control efforts and the integration of such control efforts with those of other economically important livestock vector-borne diseases that occur alongside TBDs in this area, such as trypanosomiasis.

\section{Methods}

\section{Study area}

The study was carried out in Tororo district (Figure 1) between September and December 2011. The location, farming system, climate and vegetation of the study area have been previously described [8]. At the time of the study, Tororo District had an estimated cattle population of 37,300 [18].

\section{Study design, sampling and sample size}

A complete sampling frame of all villages and their georeferences was obtained from The Coordinating office for Control of Tsetse and Trypanosomiasis in Uganda (COCTU) and verified at the District lands and planning offices. To estimate the prevalence of T. parva infections in cattle under traditional farming systems in Tororo District, 22 villages were randomly selected. Sample size was determined assuming a mean cattle population of 93 animals per village [18], anticipated prevalence of AAT of $30 \%$ [19], the precision of the sample estimate (one half-length of the $95 \%$ confidence interval) of 5\%points and an intra-cluster correlation coefficient (ICC) of 0.15 . The ICC estimate was based on reported rates of homogeneity (rho) for vector-borne diseases, noting high variability $[20,21]$.

\section{Cattle blood sample collection}

Blood samples were taken from all cattle in each of the 22 villages in Tororo District. Approximately $125 \mu \mathrm{l}$ of blood was drawn from the middle ear vein using a capillary tube. Samples were applied to Whatman FTA cards (Whatman Bioscience, Cambridge, UK), avoiding cross contamination [22]. Samples were air-dried at ambient temperature, labelled by the animal ear tag number, names of the parish, sub county, county of Tororo District. Samples were packed in foil pouches with a silica gel desiccant prior to analysis. A temporary marker was used as a means of ensuring that all cattle in the village were sampled, and that each animal was sampled only once.

\section{DNA extraction}

DNA was extracted and eluted from FTA sample discs according to Becker et al. [23]. Briefly, each FTA card was placed on a supporting base (Whatman Bio-Sciences Ltd.) and from each of the individual samples; five discs were punched out using a Harris 3.0-mm Micro Punch (Whatman Biosciences Ltd.) and discharged into $1.5 \mathrm{ml}$ Eppendorf tubes. The Micro Punch was cleaned after punching each sample by punching at least the same number of discs from a clean filter paper. A negative control was prepared by cutting the same number of discs from a sterile FTA card and processed together with field samples. Samples were washed twice for $15 \mathrm{~min}$ with $1.0 \mathrm{ml}$ FTA Purification Reagent (Whatman) followed by two rinses of $15 \mathrm{~min}$ with $1.0 \mathrm{ml} \mathrm{TE}-1$ buffer $(10 \mathrm{mM}$ Tris-HCl, $0.1 \mathrm{mM}$ EDTA, $\mathrm{pH}$ 8.0). After drying for $45 \mathrm{~min}$ at $37^{\circ} \mathrm{C}$ or at room temperature overnight, the test 


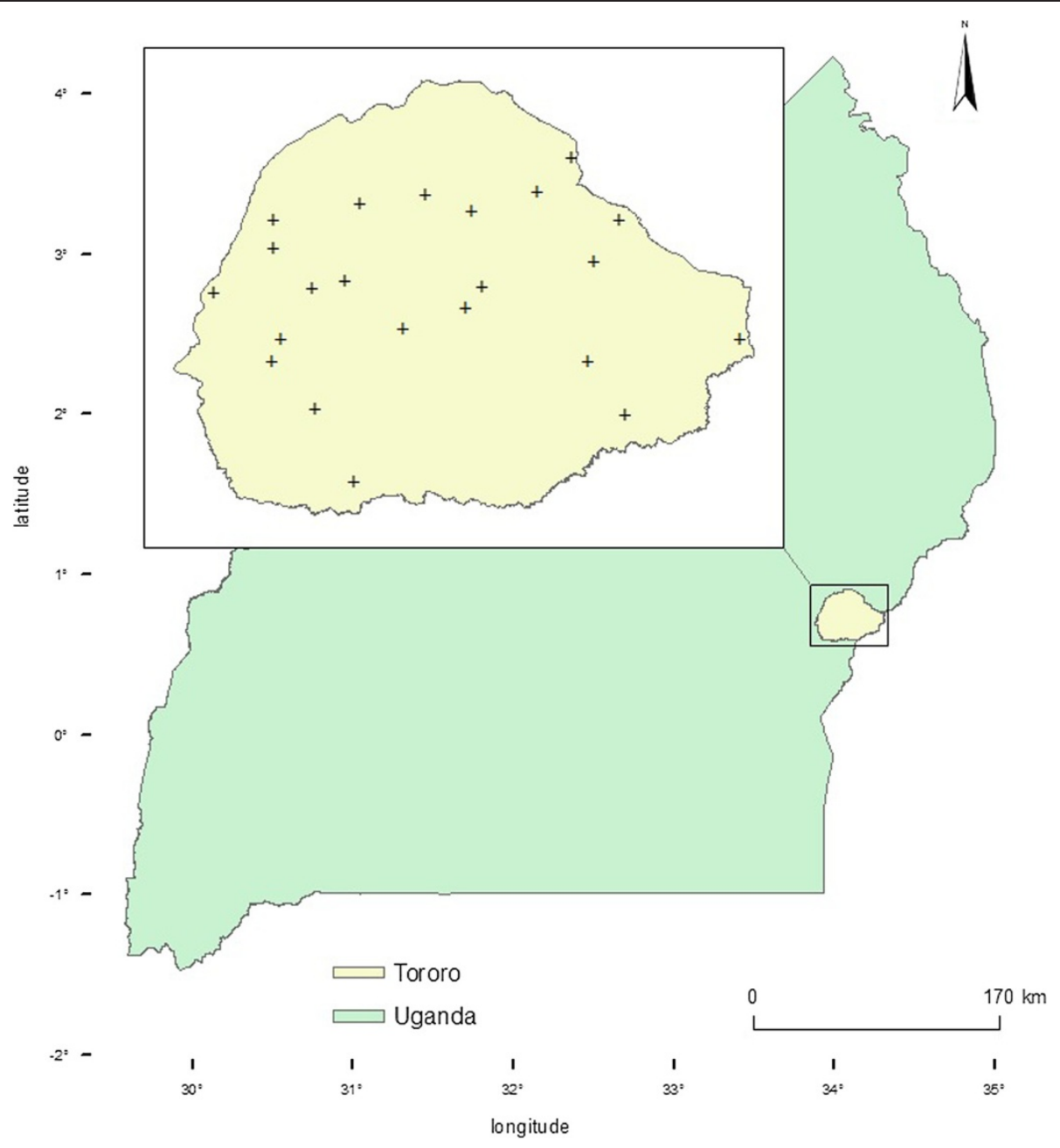

Figure 1 Geographical location of Tororo District (+ sample sites).

sample or control discs were boiled at $90^{\circ} \mathrm{C}$ for $30 \mathrm{~min}$. in DNA Engine Dyad ${ }^{\circledR}$ Cycler -PTC-0221 (Bio-Rad Laboratories Inc.) in $100 \mu \mathrm{l}$ of $5 \%(\mathrm{w} / \mathrm{v})$ aqueous suspension of Chelex 100 resin (Sodium form, 50-100 Dry mesh; BioRad Laboratories, Sigma Aldrich, Co., Life sciences, USA). Eluted DNA samples were kept at $-20^{\circ} \mathrm{C}$ for PCR analyses or $4^{\circ} \mathrm{C}$ if they were to be analyzed within a few days after extraction [22-24].

\section{Preparation of positive control DNA from T. parva sporozoite cell lines}

Control DNA was extracted from each of the two $T$. parva frozen sporozoite cell lines (201961TPM and 202094TPM), (kindly provided by Dr. Tim Connelly, of The Roslin Institute, The University of Edinburgh, Easter Bush, Midlothian, EH25 9RG, Scotland, UK) by DNeasy ${ }^{\circledR}$ blood and tissue kit (QIAGEN ${ }^{\odot}$, USA). 400ul of the DNA elute were added into a sterile $2 \mathrm{ml}$ micro centrifuge tube and mixed thoroughly by vortexing. $50 \mu \mathrm{l}$ working stock aliquots were made and kept at $4^{\circ} \mathrm{C}$ while non-working stock aliquots were stored for future use at $-20^{\circ} \mathrm{C}$. The extracted DNA was used as control DNA for T. parva p104-based PCR [25]. To ensure that the highest quality control DNA was used, the amplicon from the positive control was compared to that from $T$. parva sporozoite cell line DNA (provided by Tanguy Marcotty of the Institute of Tropical Medicine, Antwerp).

\section{T. parva detection by $\mathrm{kDa}$ antigen ( $\mathrm{p} 104)$ based PCR}

Eluted DNA samples were screened for T. parva using a single pair of primers (IL4243; 5-GGC CAA GGT CTC CTT CAG AAT ACG-3 and IL3232; 5-TGG GTG TGT TTC CTC GTC ATC TGC-3) derived from p104 single copy gene [25]. This primer set amplifies a 277 bp fragment of a highly conserved segment of p104 gene making it a very specific and sensitive target for $T$. parva diagnosis. p104-based PCR has a T. parva detection level of up to 1.4 parasites/ $\mu$ l of blood compared to 0.4 parasites/ $\mu$ l of blood when nested PCR is used. Conventional p104 based PCR was preferred to the nested PCR format 
because a large number of samples was handled making nested PCR practically impossible. PCR was performed in $25 \mu \mathrm{l}$ reaction volume; $20 \mu \mathrm{l}$ of which were the PCR master mix containing $2.55 \mu \mathrm{l}$ of $10 \times$-reaction buffer $\left(670 \mathrm{mM}\right.$ Tris- $\mathrm{HCl} \mathrm{pH} 8.8,166 \mu \mathrm{M}(\mathrm{NH} 4)_{2} \mathrm{SO}_{4}, 4.5 \%$ Triton X-100, $2 \mathrm{mg} / \mathrm{ml}$ gelatin) (Fisher Biotech), I.0 mM $\mathrm{MgCl}_{2}, 200 \mu \mathrm{M}$ of each dNTP, $5 \mu \mathrm{M}$ each of the IL3232 and IL4234 primers, $0.7 \mathrm{U}$ of BioTaq DNA polymerase (Fisher Biotech), $14.55 \mu \mathrm{l}$ RNase-free water and $5 \mu \mathrm{l}$ of sample DNA or positive control DNA or negative control eluate. PCR was carried out in a DNA Engine Dyad ${ }^{\circ}$ Cycler (PTC-0221, Bio-Rad Laboratories Inc.) at cycling conditions including a denaturation step at $95^{\circ} \mathrm{C}$ for 5 minutes, 30 cycles of denaturation at $94^{\circ} \mathrm{C}$ for 30 s each cycle, annealing at $65^{\circ} \mathrm{C}$ for $30 \mathrm{~s}$, extension at $72^{\circ} \mathrm{C}$ for 1 minute, final elongation step at $72^{\circ} \mathrm{C}$ for 5 minutes [26]. PCR products were electrophoresed in $1.5 \%$ agarose (Bio Tolls Inc.Japan), stained in GelRed ${ }^{\mathrm{mm}}$ (Biotium, Inc., USA) and visualised on a UV transilluminator.

\section{Data analysis}

Raw data were entered into Microsoft Excel $^{\mathrm{Tm}}$ and analysed using R statistical software v3.0.0. Prevalences and risk factors as well as their confidence intervals were estimated using generalized estimating equation (GEE) models with binary outcome and Logit Link Function to adjust for correlations within communities. T. parva spatial analyses were done in ArcMap software environment v10.1 using the spatial analyst extension for Inverse Distance Weighting tool.

\section{Ethical clearance}

This study was cleared by the internal review board of Makerere University College of Veterinary Medicine Animal Resources and Biosecurity and approved by The Uganda National Council for Science and Technology (Registration number HS1336).

\section{Results}

Demographic characteristics of the study population

2,658 cattle blood samples were collected from the 22 villages between September and December 2011. The mean number of cattle per village was 120 (range 60200) while the mean number of cattle per household was 4. Almost all the animals belonged to the Boran $\mathrm{x}$ short horn Zebu crossbreed. Approximately half of the population were female. The demographic characteristics of the study population are summarised in Table 1.

\section{Prevalence of $T$. parva by age, sex and breed}

The distribution of T. parva infections stratified by age, sex and breed of cattle is summarised in Table 1. Cattle older than one year of age and males were associated with a slightly higher risk of infection. However, the
Table 1 Percentage $T$. parva distribution by age, sex and breed $(\mathrm{N}=\mathbf{2 , 6 5 8})$

\begin{tabular}{|c|c|c|c|c|c|}
\hline Population attributes & $\mathrm{n}$ & Positive & $\begin{array}{l}\text { Prevalence } \\
(\%)\end{array}$ & OR & $95 \% \mathrm{Cl}$ \\
\hline \multicolumn{6}{|l|}{ a) Age } \\
\hline 0-12 months & 397 & 17 & 4.3 & Ref & \\
\hline 13-24 months & 579 & 30 & 5.2 & 1.2 & $0.6-2.6$ \\
\hline 25-36 months & 452 & 22 & 4.9 & 1.1 & $0.7-2.0$ \\
\hline$>36$ months & 1230 & 64 & 5.2 & 1.2 & $0.7-2.1$ \\
\hline \multicolumn{6}{|l|}{ b) Sex } \\
\hline Female & 1393 & 67 & 4.8 & Ref & \\
\hline Male & 1069 & 58 & 5.4 & 1.1 & $0.8-1.5$ \\
\hline Neutered & 196 & 8 & 4.1 & 0.8 & $0.4-1.8$ \\
\hline \multicolumn{6}{|l|}{ c) Breed } \\
\hline $\begin{array}{l}\text { Boran } \times \text { African short } \\
\text { horn Zebu (Nkedi) }\end{array}$ & 2570 & 129 & 5.0 & Ref & \\
\hline Boran $\times$ Holstein Friesian & 44 & 2 & 4.5 & 0.9 & $0.3-2.8$ \\
\hline $\begin{array}{l}\text { African short horn } \\
\text { Zebu (Nkedi) }\end{array}$ & 44 & 2 & 4.5 & 0.9 & $0.2-3.8$ \\
\hline
\end{tabular}

observed odds ratios were moderate and the confidence intervals included unity indicating no statistically significant difference. There was no difference in the probability of infection with $T$. parva in cattle of different breeds $(\mathrm{OR}=0.9 ; 95 \% \mathrm{CI} ; 0.2-3.8)$.

\section{Spatial distribution of $T$. parva in Tororo District}

The prevalence of $T$. parva in the 22 villages is summarised in Table 2. The overall prevalence of T. parva in cattle in Tororo District was 5.3\% (95\% CI; 3.5-8.0). The prevalence of $T$. parva at herd (village) level was highly variable ranging from $0.0 \%-21.1 \%$. In four of the 22 villages no infection was detected in any animal sampled. The majority of infections were detected in villages in the North, North-Eastern and the South-Eastern parts of the district (Figure 2).

\section{Discussion}

To determine the extent of the problem that $T$. parva presents to cattle rearing in Eastern Uganda, a cross sectional study was undertaken to determine the overall prevalence of T. parva and examine the spatial distribution of T. parva in traditional farming systems in Tororo District. T. parva herd prevalence was highly variable between villages $(0 \%-21.1 \%)$ with most of the infections detected in cattle from the North, North-Eastern and the South-Eastern parts of the district. The observed $T$. parva prevalence is in agreement with that previously observed [6] but the individual herd prevalences reported here using PCR based methods are slightly higher. Whereas the serological methods previously used [6] can determine exposure (current and present) to 
Table 2 Village (Herd) level T. parva prevalence in Tororo District

\begin{tabular}{|c|c|c|c|c|}
\hline Village & $\begin{array}{l}\text { Number } \\
\text { sampled }\end{array}$ & $\begin{array}{l}\text { Number } \\
\text { positive }\end{array}$ & $\begin{array}{l}\text { Prevalence } \\
\text { (\%) }\end{array}$ & $95 \% \mathrm{Cl}^{\mathrm{a}}$ \\
\hline Alupe B & 60 & 5 & 8.3 & $2.8-18.4$ \\
\hline Atapara-Kaleu & 155 & 14 & 9.0 & $5.0-14.7$ \\
\hline Chawolo-Sirongo B & 188 & 8 & 4.3 & $1.9-8.2$ \\
\hline Dida & 100 & 1 & 1.0 & $0.0-5.4$ \\
\hline Kadanya & 132 & 6 & 4.5 & $1.7-9.6$ \\
\hline Kajalau Central \& South & 64 & 3 & 4.7 & $1.0-13.1$ \\
\hline Kasoli A & 200 & 23 & 11.5 & $7.4-16.8$ \\
\hline Kirewa Zone & 132 & 2 & 1.5 & $0.2-5.4$ \\
\hline Macharimeri & 180 & 6 & 3.3 & $1.2-7.1$ \\
\hline Mailombiri/Molo-Akisim & 103 & 4 & 3.9 & $1.1-9.7$ \\
\hline Mikwana/Kijwala & 169 & 0 & 0.0 & $0.0-2.2$ \\
\hline Munyinyi-Magelo & 164 & 19 & 11.6 & $7.1-17.5$ \\
\hline Ngeta A & 127 & 4 & 3.1 & $0.9-7.9$ \\
\hline Nyabanja zone & 139 & 1 & 0.7 & $0.0-4.0$ \\
\hline Nyafumba A\&B & 94 & 3 & 3.2 & $0.7-9.0$ \\
\hline Oriyoyi A & 124 & 11 & 8.9 & $4.5-15.3$ \\
\hline Pabendo (Sere A) & 76 & 0 & 0.0 & $0.0-4.7$ \\
\hline Pamaraka & 80 & 0 & 0.0 & $0.0-4.5$ \\
\hline Pasaya & 104 & 2 & 1.9 & $0.2-6.8$ \\
\hline Rubuleri & 91 & 0 & 0.0 & $0.0-4.0$ \\
\hline Segero-Ojulai & 100 & 5 & 5.0 & $1.6-11.3$ \\
\hline Singisi & 76 & 16 & 21.1 & $12.5-31.9$ \\
\hline Total/Average & 2,658 & 133 & 5.3 & $3.5-8.0$ \\
\hline
\end{tabular}

ainomial exact confidence intervals for individual villages adjusted for within village correlation using Generalized estimating equation (GEE) models for the overall estimate.

infection, the p104-based PCR used in this study [25] identified current infections; p104-based PCR also has a higher sensitivity and specificity than ELISA. The p104 PCR used in the current study can detect 1.4 parasites/ $\mu \mathrm{l}$ corresponding to blood parasitaemia of $2.8 \times 10-{ }^{5} \%$ [27] and the species specificity of the p104 gene PCR assay approaches $100 \%$ [25].

Eastern Uganda exhibits a complex pattern of tick challenge with some villages classified as low tick challenge and others as high-tick challenge villages [6]. Low tick-challenge villages were defined as having an average tick infestation rate from $10-70 \%$ while high-tick challenge villages recorded a tick infestation that exhibited narrow variation from $90-100 \%$ [6]. The spatial distribution of $T$. parva has been shown to mirror that of the tick challenge. The herd seroprevalence of $T$. parva was previously reported to range from $4-5 \%$ in villages with low tick challenge and 4-12\% in high tick challenge villages [6]. This divergence was thought to relate to the presence of a high density of anti-tick plants (Lantana camara and Ocimum suave) in villages with low tick challenge and their absence in villages with high tick challenge [6], among other factors. O. suave contains oil extracts that can repel and kill all stages of $R$. appendiculatus ticks while L. camara oil extracts have been shown to exhibit insecticidal activities [28,29]. The distribution of these plants together with factors such as the microclimate in different villages and variations in the rate at which tick handpicking (a major tick control method) is undertaken may all contribute to the observed spatial variation in the distribution of $T$. parva in Tororo villages.

Almost all cattle sampled in Tororo District were Boran and African short horn Zebu (Nkedi) hybrids and Nkedi [30]. No statistical significant difference in terms of infection with $T$. parva could be established between the predominant breed and other minority breeds in this area largely due to low numbers of other breeds in the sample. African Short horn Zebu (Nkedi) and other African local breeds are reported to be relatively resistant to ticks and tick-borne hemoparasites infections (as compared to exotic animals) and when exposed to infection show a reduced likelihood of developing clinical disease [12,31].

The observed increase of infection with $T$. parva with cattle age may be explained in two ways: i) Maternal antibodies to T. parva wane at about 6 months of age $[12,31]$. Cattle that are more than one year of age have protection from infection by $T$. parva and the progression to clinical disease from acquired immunity developed as a result of exposure to infection as calves (when they were protected by maternal immunity). Previous reports have shown high rates of seroconversion to $T$. parva in calves between $0-6$ months in both low and high tick challenge communities and seroconversion rates that parallel tick challenge levels in older cattle [16]. The present study showed slightly elevated prevalences in older cattle that may relate to the sustained tick challenge these animals received under traditional grazing systems, with over $90 \%$ of the cattle exposed to tick challenge $[8,9]$. However, in villages with low tick challenge, a small younger animal population could have been exposed to T. parva and most cattle remained susceptible and would seroconvert on subsequent exposure. This situation is likely to maintain a population of susceptible individuals that could be affected by ECF on exposure to T. parva infection.

ii) In traditional grazing systems, calves are confined, fed at home and are not permitted to graze with adults to limits their exposure to ticks $[32,33]$. The only time calves between $0-12$ months mix with their dams is at the time of milking when they are used to stimulate let-down of milk. This practice keeps calves highly susceptible to TBDs especially at the point at which their maternal antibodies decline 


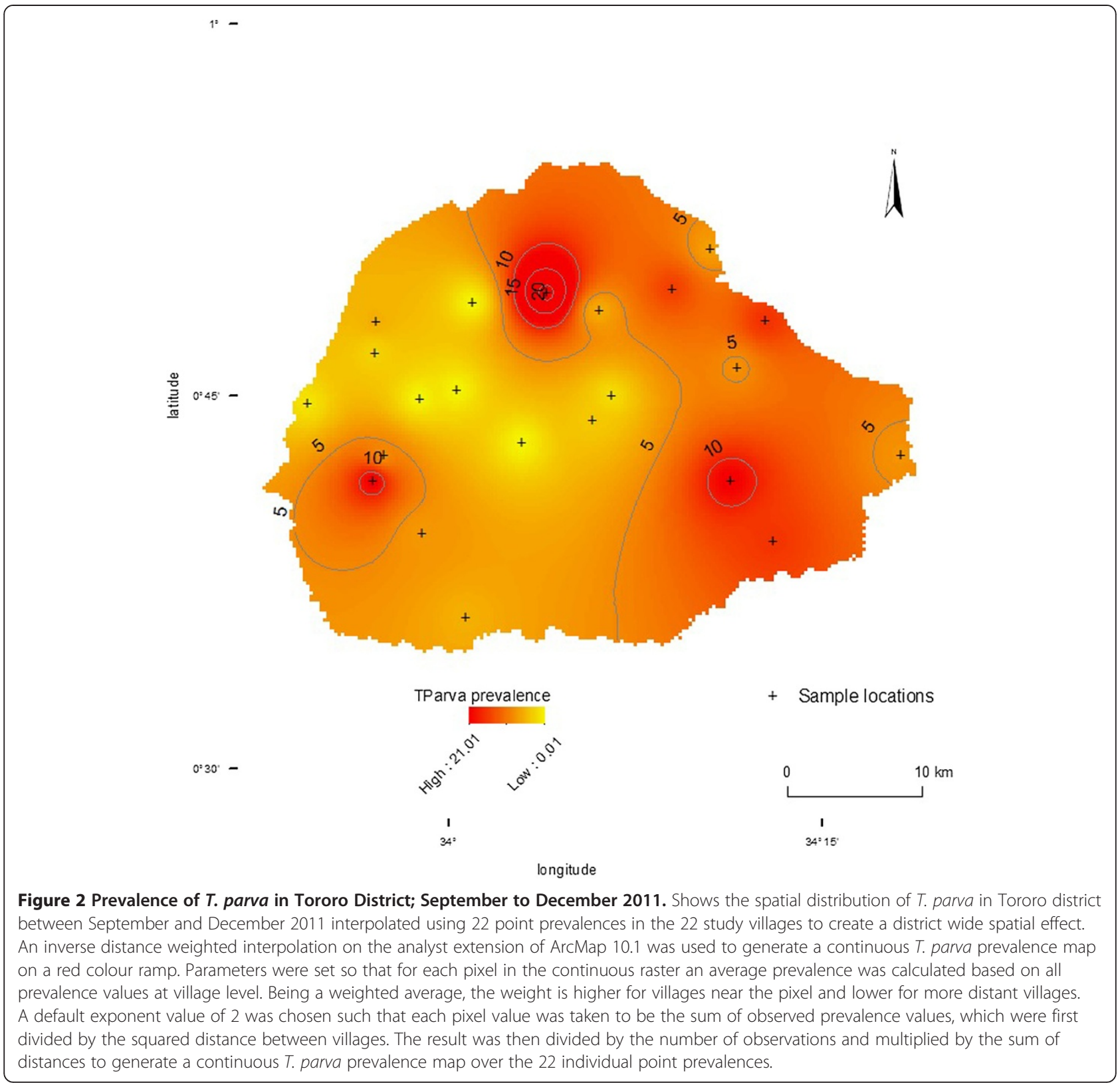

(above 6 months of age) and these animals are likely to seroconvert on exposure to T. parva infections with the chance of progression to clinical disease.

The extent to which the scenarios (i) and (ii) are likely to lead to the development or disruption of endemic stability development to ECF and other TBDs in Uganda is unclear. It is usually held that indigenous cattle are exposed to constant tick challenge under traditional grazing systems in the crop-livestock production system in Uganda and are therefore likely to develop endemic stability to TBDs and suffer minimal disease; there is however sufficient spatial and seasonal variation in tick abundance/distribution to question this assumption [6]. The current study has shown a high degree of spatial variation in the distribution of T. parva that appears to be related to previously reported spatial tick abundance/ distribution in Eastern Uganda [6].

Male cattle were associated with a slightly higher probability of infection with $T$. parva than females and castrates, that may be due to a reduction in activity in the individual associated with castration and a reduction of testosterone levels in castrates [34]. Lower physiological activity in females and castrates is associated with lower grazing activity resulting in a reduced probability of the animal encountering $R$. appendiculatus and therefore exposure to infection with T. parva [34]. In Eastern Uganda the male to female cattle ratio is high (0.9) since farmers retain many bulls (whole or neutered) for draft power. 
This herd structure, dominated by animals above 3 years of age and bulls (whole or neutered), is geared towards developing animal traction [35]. Animal traction is the main source of labour in these crop-livestock agricultural systems with bullocks being used to cultivate more than half of their crop fields. The observed slight reduction in the probability of infection with T. parva in castrates may be the result of farmers applying preferential tick control (for example tick hand picking) to these animals since bullocks have more value as they are used to provide draft power.

\section{Conclusion}

The prevalence of $T$. parva infections in cattle in different communities in Tororo is highly variable with over a quarter of the animals being infected with $T$. parva in some villages. The prevalence and distribution of $T$. parva is most likely determined by spatial distribution of $R$. appendiculatus, restricted grazing of calves and preferential tick control in draft animals. There is a need to understand the local epidemiology at village level with regard to endemic stability development or its disruption and how these parameters may be exploited in guiding and prioritising TBD control. Routine application of acaracides to cattle is a cost-effective control method that farmers can adopt for both tsetse and tick control in Uganda [36] and is crucial to the long-term success for control of Rhodesian sleeping sickness in Uganda [37].

\section{Competing interests}

The authors hereby declare no competing interests. The sponsors had no role in the study design, data collection and analysis, decision to publish, or preparation of the manuscript.

\section{Authors' contributions}

DM, MT, JDK, CW and SCW conceived and designed this study. DM carried out blood sample collection and PCR analysis. DM and JH carried out statistical analysis. All the authors participated in the manuscript write up and final approval.

\section{Acknowledgements}

This study received funding from ICONZ (EU-FP7) work package 8 under grant agreement no 2948. Authors wish to acknowledge the assistance of the cattle keepers and that of the Tororo district Production Department during blood sample collection and the input of Ward Bryssinckx (of Avia-G/S) for helping with use of ArcMap software in general mapping and spatial data analysis.

\footnotetext{
Author details

${ }^{1}$ College of Veterinary Medicine Animal Resources and Biosecurity, Makerere University, P.O. Box 7062, Kampala, Uganda. ${ }^{2}$ Centre for Infectious Diseases, School of Biomedical Sciences, College of Medicine and Veterinary Medicine, The University of Edinburgh, Chancellor's Building, 49 Little France Crescent, Edinburgh, EH16 4SB, UK. ${ }^{3}$ Swiss Tropical and Public Health Institute, Department of Public Health and Epidemiology, Socinstrasse 57, CH-4002 Basel, Switzerland. ${ }^{4}$ Royal (Dick) School of Veterinary Studies, The University of Edinburgh, Edinburgh EH25 9RG, UK.
}

Received: 30 January 2014 Accepted: 25 February 2014

Published: 3 March 2014

\section{References}

1. Jongejan F, Uilenberg G: The global importance of ticks. Parasitology 2004, 129(Suppl):S3-S14

2. Okello-Onen J, Tukahirwa EM, Perry BD, Rowlands GJ, Nagda SN, Musisi G, Bode E, Heinonen R, Mwayi W, Opuda-Asibo J: The impact of tick control on the productivity of indigenous cattle under ranch conditions in Uganda. Trop Anim Health Prod 2003, 35(3):237-247.

3. Uilenberg G: International collaborative research: significance of tickborne hemoparasitic diseases to world animal health. Vet Parasitol 1995, 57(1-3):19-41.

4. Kivaria FM: Estimated direct economic costs associated with tick-borne diseases on cattle in Tanzania. Trop Anim Health Prod 2006, 38(4):291-299.

5. McKeever DJ: Bovine immunity - a driver for diversity in Theileria parasites? Trends Parasitol 2009, 25(6):269-276.

6. Magona JW, Walubengo J, Olaho-Mukani W, Jonsson NN, Welburn SC, Eisler MC: Spatial variation of tick abundance and seroconversion rates of indigenous cattle to Anaplasma marginale, Babesia bigemina and Theileria parva infections in Uganda. Exp Appl Acarol 2011, 55(2):203-213.

7. Magona JW, Walubengo J, Olaho-Mukani W, Jonsson NN, Welburn SC, Eisler MC: Clinical features associated with seroconversion to Anaplasma marginale, Babesia bigemina and Theileria parva infections in African cattle under natural tick challenge. Vet Parasitol 2008, 155(3-4):273-280.

8. Magona JW, Greiner M, Mehlitz D: Impact of tsetse control on the agespecific prevalence of trypanosomosis in village cattle in southeast Uganda. Trop Anim Health Prod 2000, 32(2):87-98.

9. Okiria R, Okuna NM, Magona JW, Mayende JS: Sustainability of tsetse control by subsequent treatment of $10 \%$ of a previously treated Ugandan cattle population with $1 \% \mathrm{w} / \mathrm{v}$ deltamethrin. Trop Anim Health Prod 2002, 34(2):105-114.

10. Mahoney DF, Ross DR: Epizootiological factors in the control of bovine babesiosis. Aust Vet J 1972, 48(5):292-298.

11. Rogers RJ, Shiels IA: Epidemiology and control of anaplasmosis in Australia. J S Afr Vet Assoc 1979, 50(4):363-366.

12. Norval RAI, Perry BD, Young AS: The Epidemiology of Theileriosis in Africa. London: Academic; 1992

13. Mettam RWM, Carmichael J: Turning sickness, a Protozoan Encephalitis of Cattle in Uganda. Its relationship with East Coast fever. Parasitology 1936, 28(02):254-283.

14. Perry BD, Young AS: The naming game: the changing fortunes of East Coast fever and Theileria parva. Vet Rec 1993, 133(25-26):613-616.

15. Rubaire-Akiiki C, Okello-Onen J, Nasinyama GW, Vaarst M, Kabagambe EK, Mwayi W, Musunga D, Wandukwa W: The prevalence of serum antibodies to tick-borne infections in Mbale district, Uganda: the effect of agroecological zone, grazing management and age of cattle. J Ins Sci 2004, 4(8):1-8.

16. Rubaire-Akiiki C, O-O J, Musunga D, Kabagambe EK, Vaarst M, Okello D, Opolot C, Bisagaya A, Okori C, Bisagati C, Ongyera S, Mwayi MT: Effect of agro-ecological zones and grazing system on the incidence of East cost fever in calves in Mbale and Sironko Districts of Eastern Uganda. Prev Vet Med 2006, 75:251-266.

17. Tosas AO: Theileria Parva: Inter- and Intra-Species Interactions in the Community of Endemic Pathogens of African Cattle. PhD Thesis. Edinburgh: The University of Edinbrugh; 2006

18. Anonymous: The National Livestock Census: A Summary Report of the National Livestock Census, 2008. Uganda Bureau of Statistics: Ministry of Agriculture Animal Industry and Fisheries; 2009:41.

19. Bohning D, Greiner M: Prevalence estimation under heterogeneity in the example of bovine trypanosomosis in Uganda. Prev Vet Med 1998, 36(1):11-23.

20. Orjuela J, Navarrete M, Betancourst A, Roqueme L, Cortez E, Morrison RB: Salud y productividad en bovines de la costa norte en Colombia. 2. Hallazgos, serologicos, bacteriologicos y parasitologicos. World Anim Rev 1991, 69:7-14

21. Dhalwa J: Animal Health and Production Constraints in Traditional Farming Systems in Mbarara District. Uganda: University of Reading; 1995.

22. Ahmed HA, MacLeod ET, Hide G, Welburn SC, Picozzi K: The best practice for preparation of samples from $\mathrm{FTA}^{(\mathrm{R})}$ cards for diagnosis of blood borne infections using African trypanosomes as a model system. Parasit Vectors 2011, 4:1756-3305.

23. Becker S, Franco JR, Simarro PP, Stich A, Abel PM, Steverding D: Real-time PCR for detection of Trypanosoma brucei in human blood samples. Diag Microbiol Infect Dis 2004, 50(3):193-199. 
24. Picozzi K, Carrington M, Welburn SC: A multiplex PCR that discriminates between Trypanosoma brucei brucei and zoonotic $T$. b. rhodesiense. Exp Parasitol 2008, 118:41-46.

25. Skilton RA, Bishop RP, Katende JM, Mwaura S, Morzaria SP: The persistence of Theileria parva infection in cattle immunised using two stocks which differ in their ability to induce a carrier state: analysis using a novel blood spot PCR assay. Parasitology 2002, 124:265-276.

26. Konnai S, Imamura S, Nakajima C, Witola WH, Yamada S, Simuunza M, Nambota A, Yasuda J, Ohashi K, Onuma M: Acquisition and transmission of Theileria parva by vector tick, Rhipicephalus appendiculatus. Acta Trop 2006, 99(1):34-41.

27. Odongo DO, Sunter JD, Kiara HK, Skilton RA, Bishop RP: A nested PCR assay exhibits enhanced sensitivity for detection of Theileria parva infections in bovine blood samples from carrier animals. Parasitol Res 2010, 106(2):357-365.

28. Mwangi EN, Hassanali A, Essuman S, Myandat E, Moreka L, Kimondo M: Repellent and acaricidal properties of Ocimum suave against Rhipicephalus appendiculatus ticks. Exp Appl Acarol 1995, 19(1):11-18.

29. Dua VK, Pandey AC, Dash AP: Adulticidal activity of essential oil of Lantana camara leaves against mosquitoes. IndianJ Med Res 2010, 131:434-439.

30. Magona JW, Walubengo J, Odimim JJ: Differences in susceptibility to trypanosome infection between Nkedi Zebu and Ankole cattle, under field conditions in Uganda. Ann Trop Med Parasitol 2004, 98(8):785-792.

31. Lawrence JA, Musisi FL, Mfitilodze MW, Tjornehoj K, Whiteland AP, Kafuwa PT, Chamambala KE: Integrated tick and tick-borne disease control trials in crossbred dairy cattle in Malawi. Trop Anim Health Prod 1996, 28(4):280-288.

32. Muhanguzi D, Matovu E, Waiswa C: Prevalence and characterization of Theileria and Babesia species in cattle under different husbandry systems in western Uganda. Int J Anim Veter Adv 2010, 2(2):51-58.

33. Muhanguzi D, Ikwap K, Picozzi K, Waiswa C: Molecular characterization of anaplasma and ehrlichia species in different cattle breeds and Age groups in mbarara district (Western Uganda). Int J Anim Veter Adv 2010, 2(3):76-88.

34. Marti S, Realini C, Bach A, Pérez-Juan M, Devant M: Effect of castration and slaughter age on performance, carcass, and meat quality traits of Holstein calves fed a high-concentrate diet. J Anim Sci 2013, 91(3):1129-1140.

35. Ocaido M, Otim CP, Okuna NM, Erume J, Ssekitto C, Wafula RZO, Kakaire D, Walubengo J, Monrad J: Socio-economic and livestock disease survey of agro-pastoral communities in Serere County, Soroti District, Uganda. Livest Res Rural Dev 2005, 17:Art. \#93.

36. Kajunguri D, Hargrove JW, Ouifki R, Mugisha JYT, Coleman JP, Welbun SC: Modelling the control of tsetse and Trypanosoma brucei rhodesience in a multi-host population through insecticide-treated cattle. Bull Math Biol 2013. In press.

37. Bardosh K, Waiswa C, Welburn SC: Conflict of interest: use of pyrethroids and amidines against tsetse and ticks in zoonotic sleeping sickness endemic areas of Uganda. Parasit Vectors 2013, 6:1756-3305.

doi:10.1186/1756-3305-7-91

Cite this article as: Muhanguzi et al:: Prevalence and spatial distribution of Theileria parva in cattle under crop-livestock farming systems in Tororo District, Eastern Uganda. Parasites \& Vectors 2014 7:91.

\section{Submit your next manuscript to BioMed Central and take full advantage of:}

- Convenient online submission

- Thorough peer review

- No space constraints or color figure charges

- Immediate publication on acceptance

- Inclusion in PubMed, CAS, Scopus and Google Scholar

- Research which is freely available for redistribution

Submit your manuscript at www.biomedcentral.com/submit
Ciomed Central 